\title{
Spatial and temporal variability of the zooplankton community at Araruama Lagoon
}

\author{
Judson da Cruz Lopes da Rosa ${ }^{1}$ \\ Lucas Lemos Batista ${ }^{2}$ \\ Universidade Federal do Rio de Janeiro \\ Programa de Pós-Graduação em Ciências Ambientais e Conservação \\ ${ }^{1}$ Laboratório Integrado de Zoologia \\ ${ }^{2}$ Laboratório Invertebrados \\ Macaé - RJ, Brasil \\ * Autor para correspondência \\ judsoncruz@yahoo.com.br
}

Submetido em 26/11/2019

Aceito para publicação em 09/08/2020

\section{Resumo}

Variação espacial e temporal da comunidade zooplanctônica na Lagoa de Araruama. Em ambientes hipersalinos a comunidade zooplanctônica geralmente é pobre em densidade e riqueza, mesmo assim esses organismos são fundamentais para a base da cadeia alimentar local. O presente estudo tem como objetivo avaliar a variação espacial e temporal da comunidade zooplanctônica da Lagoa de Araruama, considerando os dados abióticos de salinidade e temperatura e os dados bióticos densidade e composição do zooplâncton. Foram realizadas seis amostragens em 12 estações de coleta a partir de arrastos de superfície horizontais, utilizando redes de malha de $200 \mu \mathrm{m}$ com uma abertura de $60 \mathrm{~cm}$ de diâmetro e um medidor de vazão acoplado. Foram identificados um total de 34 táxons holoplanctônicos e cinco grupos de meroplâncton. Em relação a variação espacial e temporal do zooplâncton da lagoa, os parâmetros avaliados apresentaram resultados significativos para ambos os fatores. As variações também apresentaram maior riqueza, diversidade e densidade de espécies nas estações de coleta mais próximas do mar, onde a salinidade foi mais baixa. Houve predominância do holoplâncton durante o estudo, diferente dos resultados encontrados na década de 90.

Palavras-chave: Ambientes hipersalinos; Holoplanctônicas; Meroplâncton

\section{Abstract}

In hypersaline environments the zooplankton community is generally poor in density and richness, even so these organisms are fundamental to the base of the local food chain. This study aims to evaluate the spatial and temporal variation of the zooplankton community of Araruama Lagoon, considering the abiotic data of salinity and temperature as well as the biotic data of zooplankton density and composition. Six samples were performed in 12 collection stations from horizontal surface halls with $200 \mu \mathrm{m}$ mesh nets with a $60 \mathrm{~cm}$ diameter opening and an attached flowmeter. A total of 34 holoplanktonic taxa and five groups of meroplankton were identified. In relation to the spatial and temporal variation of the zooplankton of the lagoon, the parameters evaluated showed significant results for both factors. The variations also showed greater richness, diversity and density of species in the collection stations closer to the sea, where salinity was lower. There was a predominance of holoplankton during the study, differing from the results previously found in the 90's.

Key words: Holoplankton; Hypersaline environments; Meroplankton 


\section{Introduction}

The planktonic community in aquatic ecosystems is the basis of the functioning quality of these environments, since it constitutes the initial trophic levels (FERNANDES et al., 2017). The zooplankton community is composed of prokaryotes and metazoan organisms (CALBET et al., 2000), being represented by many invertebrates, eggs and fish larvae. The community is made up of several groups that include organisms from the simplest structures (ciliates) to the most complex (fish larvae). In the coastal marine zooplankton community, copepods represent about $80 \%$ of the community abundance (HIRST; BUNKER, 2003). These crustaceans are excellent indicators of the physical and chemical characteristics of the water mass. This can be noted by observing that the relative abundance and diversity of Oithonidae were the most relevant indicator of anthropogenic pollution. Oithona nana, Euterpina acutifrons and Acartia clausi can be found in areas under different degrees of pollution (DRIRA et al., 2017). In the zooplankton, groups that have the complete life cycle in the plankton are called holoplankton. Organisms that pass only the first stages of life in the plankton are called meroplankton. Although not always abundant, at some point meroplankton eggs and larvae may stand out in terms of relative abundance. (BONECKER et al., 2009; BELGRANO et al., 1995; ANGER, 2002).

The zooplankton community of a hypersaline environment is usually poor in density and richness (BUSKEY et al., 1998). In general, there are few environments with salinity above $45 \%$, and this partly justifies the lack of studies in these places (COSTA et al., 2014). Low zooplankton density may be related to low phytoplankton quality and quantity in hypersaline environments (COUTINHO et al., 1999). Although Araruama Lagoon is the largest hypersaline lagoon in the world, there are still few studies on planktonic community (SCHUINDT et al., 2018). The Araruama Lagoon is a hypersaline estuary that suffers from the discharge of in natura sewage and with this the nutrients of the water column increased according to the years (COUTINHO et al., 1999). This has caused a bloom of microalgae (CARVALHO et al., 2014). The entry of freshwater into the lagoon causes a decrease in salinity. The change in salinity affects the composition of plankton (RODRIGUES, 1998; ROSA et al., 2016a; 2016b). In addition to sewage pollution, the lagoon also suffers from invasive species such as the copepoda Temora turbinata and the cladocera Pleopis schmackeri (CARVALHO et al., 2014).

The zooplankton varies both in spacial and temporal scale, a factor that emphasizes the importance of looking for the understanding of this variation, since the variation is essential for the dynamics of trophic food webs in marine ecosystems (CHEN; LIU, 2015), and since it can influence the distribution of species with higher trophic levels, such as fish of commercial or non-commercial interest (ROBINSON et al., 2014). In this context, this study proposes to evaluate the spatial and temporal variation of the zooplankton community (holoplankton and meroplankton) in the Araruama Lagoon and associated with the environmental conditions.

\section{Materials and Methods}

\section{Study area}

The Araruama Lagoon is located in the state of Rio de Janeiro between the latitudes of $22^{\circ} 40^{\prime}$ and $22^{\circ} 57^{\prime} \mathrm{S}$ and longitudes of $42^{\circ} 00^{\prime}$ and $42^{\circ} 23^{\prime} \mathrm{W}$ (Figure 1), on the Fluminense coast. The lagoon is shallow, with an average depth of $3 \mathrm{~m}$ and maximum of $17 \mathrm{~m}$. The area of the lagoon is $210 \mathrm{~km}^{2}$. The lagoon receives marine waters through a narrow channel (Canal do Itajurú in Cabo Frio) that is $14 \mathrm{~km}$ in extension and passes through the municipalities, Araruama, Iguaba, São Pedro da Aldeia, Arraial do Cabo and Cabo Frio that have been discharging sewage in natura since 1980 (PEREIRA, 2007).

\section{Sampling}

Six samples were conducted on different types of tide, May 2012 (ebb), October 2012 (ebb), December 2012 (flood), March 2013 (flood), June 2013 (flood) and December 2013 (flood). Subsurface salinity was measured by a refractometer, temperature by a portable oximeter (Hanna HI9146-04) and zooplankton were sampled in 12 sampling stations which are located near 
FIGURE 1: Map of the Rio de Janeiro state coast highlighting the 12 sampling stations in Araruama Lagoon. The black points are sampling sites.

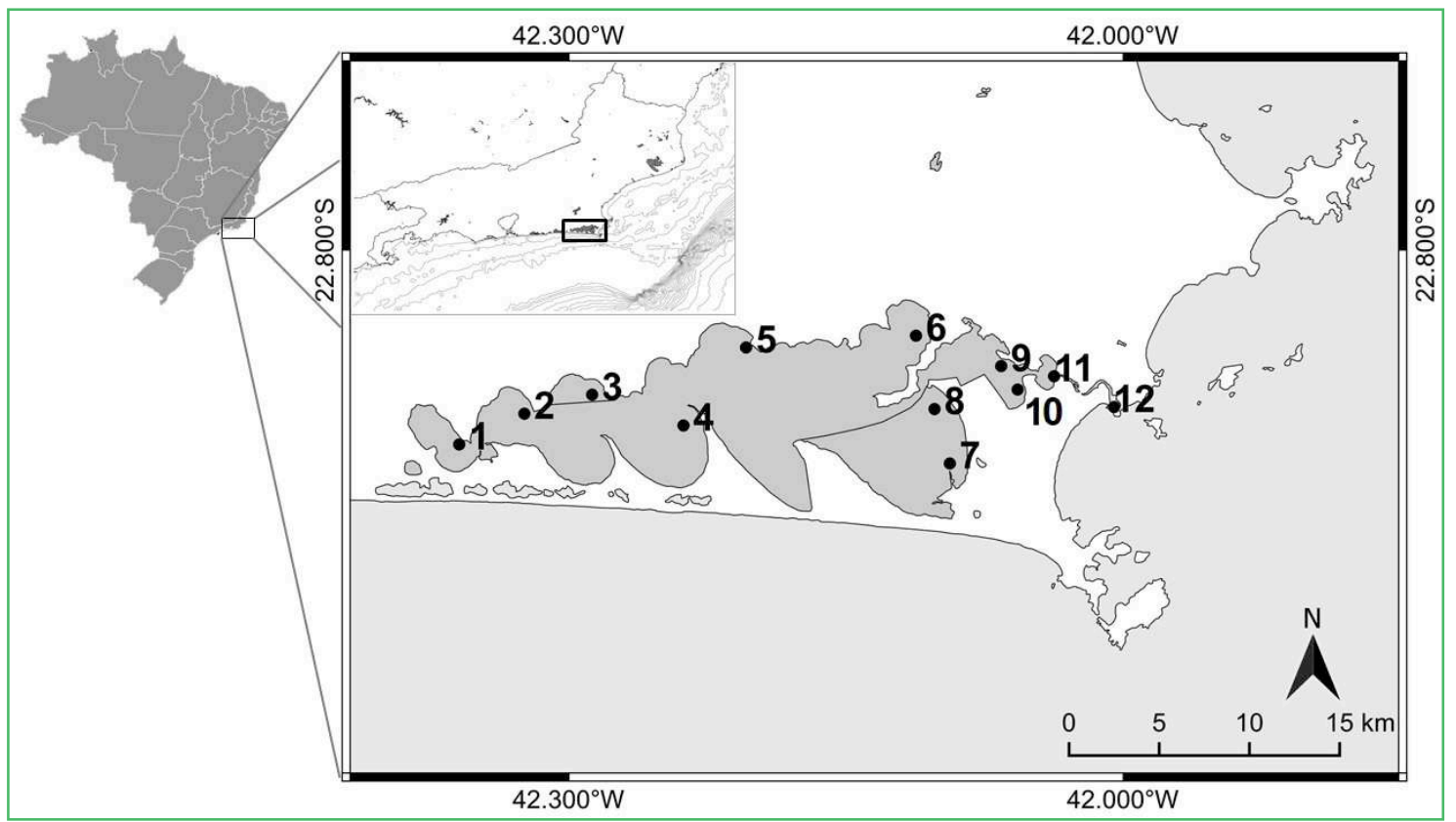

the surface, defined a priori: Ponta dos Excursionistas (station 1), Araruama Centro (station 2), Barbudo (station 3), Acaíra (station 4), Iguaba Grande (station 5), São Pedro d'Aldeia (station 6), Monte Alto (station 7), Boqueirão (station 8), Área 2 (station 9), Siqueira (station 10), Palmeiras (station 11), Boca da Barra (station 12) (Figure 1; Table 1).

\section{Zooplankton community}

Horizontal surface halls were performed with $200 \mu \mathrm{m}$ mesh nets and $60 \mathrm{~cm}$ diameter opening mouth, coupled with a flowmeter and obtaining a total of 72 samples. Immediately, the samples were fixed in a $4 \%$ formalin solution diluted in water from the lagoon and previously neutralized with sodium tetraborate. In laboratory, qualitative and quantitative analyses of zooplankton samples were performed at the lowest possible taxonomic level. Under the stereoscopic microscope, sub-samples were taken using a modified Stempel pipette $(3.0 \mathrm{~mL})$. Taxonomy and species ecology were analyzed according to Boltovskoy (1981; 1999). The World Register of Marine Species website (WoRMS: http://www.marinespecies.org) was used to confirm the current species names. All data were standardized and contrasted with previous data provided

TABLE 1: Latitude, longitude, and station depth of the sampling period.

\begin{tabular}{ccccccc}
\hline Stations & $\mathbf{1}$ & $\mathbf{2}$ & $\mathbf{3}$ & $\mathbf{4}$ & $\mathbf{5}$ & $\mathbf{6}$ \\
\hline Latitude & $22^{\circ} 53^{\prime} 10$ & $22^{\circ} 54^{\prime} 56$ & $22^{\circ} 50^{\prime} 47$ & $22^{\circ} 51^{\prime} 10$ & $22^{\circ} 53^{\prime} 42$ & $22^{\circ} 52^{\prime} 42$ \\
Longitude & $42^{\circ} 06^{\prime} 08$ & $42^{\circ} 05^{\prime} 38$ & $42^{\circ} 06^{\prime} 44$ & $42^{\circ} 12^{\prime} 15$ & $42^{\circ} 14^{\prime} 17$ & $42^{\circ} 17^{\prime} 15$ \\
Depth & 1.5 & 2.5 & 3.9 & 5.3 & 5.2 & 2.4 \\
\hline Stations & $\mathbf{7}$ & $\mathbf{8}$ & $\mathbf{9}$ & $\mathbf{1 0}$ & $\mathbf{1 1}$ & $\mathbf{1 2}$ \\
\hline Latitude & $22^{\circ} 53^{\prime} 19$ & $22^{\circ} 54^{\prime} 19$ & $22^{\circ} 4^{\prime} 37$ & $22^{\circ} 52^{\prime} 32$ & $22^{\circ} 52^{\prime} 6$ & $22^{\circ} 53^{\prime} 6$ \\
Longitude & $22^{\circ} 19^{\prime} 27$ & $42^{\circ} 21^{\prime} 34$ & $42^{\circ} 4^{\prime} 44$ & $42^{\circ} 3^{\prime} 26$ & $42^{\circ} 2^{\prime} 15$ & $42^{\circ} 00^{\prime} 18$ \\
Depth & 1.4 & 2.6 & 1.2 & 1.0 & 2.3 & 5.5 \\
\hline
\end{tabular}


by Rodrigues (1998) for the same region in order to check for a long-term change.

\section{Statistical analysis}

In order to approach the spatial and temporal variation, bar graphs were made over the months and sampling stations, as the zooplankton density is much higher in stations 12, 11 and 10, the bars were cut to show the variation of the other sampling stations. In addition, the frequency of occurrence (\%) and the relative abundance (\%) were analyzed considering all the stations and the six months of sampling. The data were transformed by the $\log (x+1)$ to decrease the influence of the most abundant species (FIELD et al., 1982). The coefficient of similarity of Bray-Curtis was used and the groups were merged by the simple mean - UPGMA. The spatial variation of the zooplankton community along the lagoon was observed by MDS analysis. This technique was utilized to represent complex relationships in a reduced dimensional space (McCUNE; GRACE, 2002). SIMPER similarity analysis was performed to test the similarities between each sampling station. This analysis identifies the individual contribution of species to the distinction between two or more sample groups (CLARKE; AINSWORTH, 1993; CLARKE et al., 2006). The results of the SIMPER analysis were presented in a bar chart and only the species with a percentage above $3 \%$ were presented. ANOSIM was tested to indicate differences between spatial and temporal variation. This analysis is used to test the null hypothesis of homogeneity of species composition in defined groups of samples (CLARKE; GREEN, 1988). The community structure was described in terms of the ShannonWeaver (H') diversity index and Pielou's evenness (J'). An Analysis of Variance (two-away ANOVA) was performed to test significant differences between the mean values for richness and density according temporal and spatial variability of the zooplankton community. Zooplankton abundance was logarithmized and data normality was tested using the Shapiro \& Wilk test (SHAPIRO; WILK, 1965).

\section{Results}

The average temperature was $27^{\circ} \mathrm{C} \pm 2.6^{\circ} \mathrm{C}$ and ranged from $21^{\circ} \mathrm{C}$ to $31^{\circ} \mathrm{C}$. The coldest temperatures were found in winter (June 2013) and the warmest in autumn (March 2013). The average salinity a was $46 \pm 5.7 \%$ and during the study ranged from $36 \%$ to $53 \%$ (Figure 2). Generally, lower salinities were found in summer (December 2012) and the high salinities in winter (June 2013).

During the study period of 32 holoplanktonic taxa were identified (Figure 3). The Copepoda group contributed with 24 species. The Cladocera group was represented by 3 species. Pteropoda by 2 species. Appendicularia by 1 species (these groups were identified at species level). Hydromedusae, Siphonophorae and meroplankton (Polychaeta, Cirripedia, Ascidiacea, Ostreidae and Mytilidae) have not been identified at the species level. The lagoon presents great richness in the stations near to the ocean (stations 12, 11 and 10), and very poor in the stations further inland (stations 9 to 1 ). In terms of temporal variation, richness values varied significantly over the months $(\mathrm{F}=3.192 ; \mathrm{p}=0.0124)$ and in terms of spatial variation they also showed significant differences $(F=45.42 ; p=0.000513)$. In addition, there was an interaction between spatial and temporal variation $(F=6.078 ; p=0.000137)$.

The average density values $\left(290 \pm 581\right.$ inds. $\left.\mathrm{m}^{-3}\right)$ showed high seasonality, with zooplankton peaks in June 2013 (winter) with 2,795 inds. m $^{-3}$ at station 12 and the lowest value in March (autumn) in station 3 and June (winter) in station 6 with 3 inds.m ${ }^{-3}$ (Figure 3). In terms of temporal variation, the density values varied significantly over the months $(F=2.795 ; \mathrm{p}=0.024)$ and in terms of spatial variation they also showed significant differences $(\mathrm{F}=49.14 ; \mathrm{p}=0.000167)$. Moreover, there was an interaction between the factors $(\mathrm{F}=3.671$; $\mathrm{p}=0.005925)$. 
FIGURE 2: Temporal variability of temperature (A) and salinity (B) in the Araruama Lagoon during the sampling period.

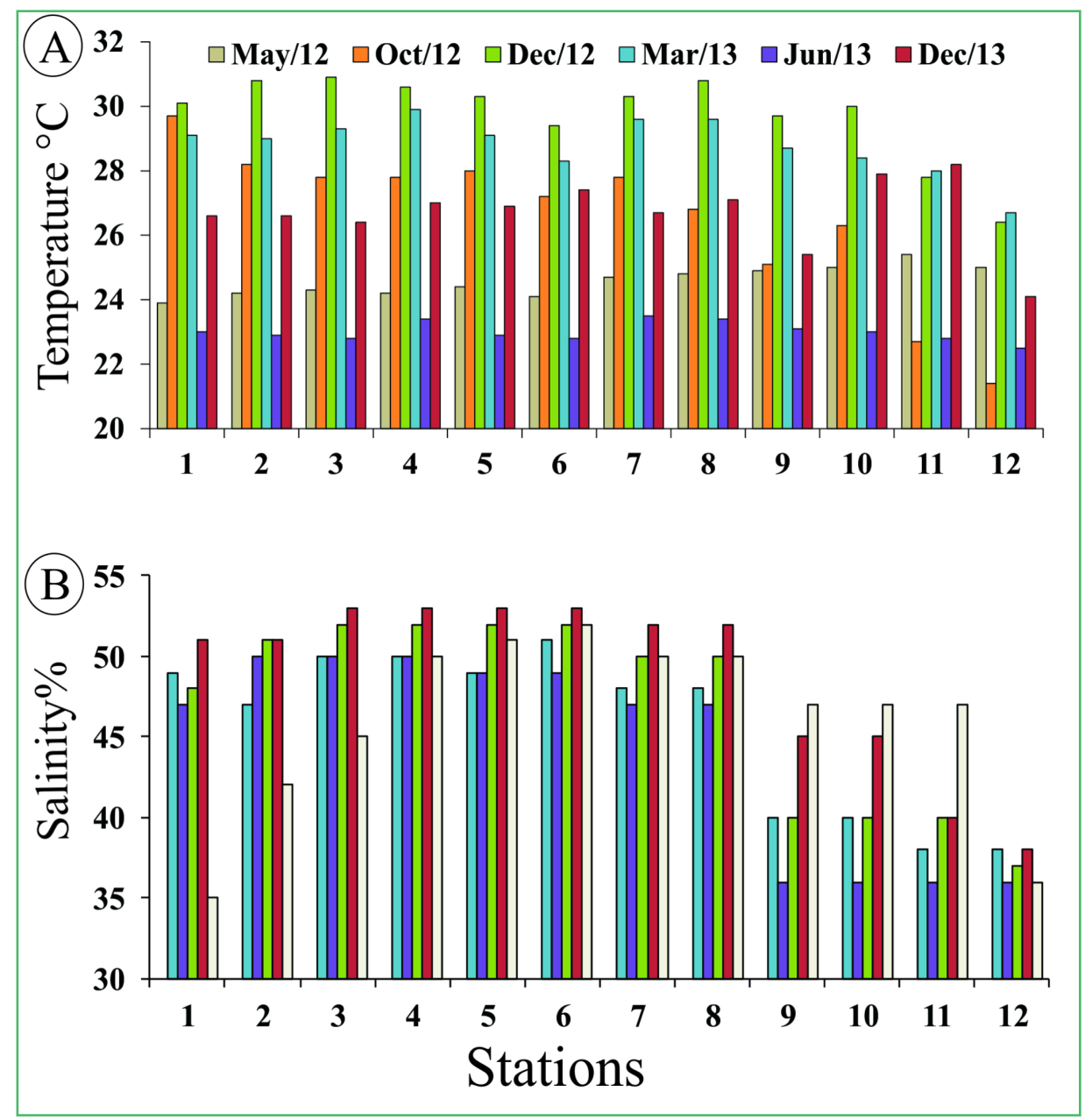

Acartia tonsa (frequency of occurrence 99\% and relative abundance $36 \%$ ) and Cirripedia larvae (frequency of occurrence $80 \%$ and relative abundance $18 \%)$ presented the highest relative abundance and frequency of occurrence among all the zooplankton taxonomic groups (Table 2). The relative abundance of A. tonsa decreases in stations 11 and 12 where salinity and temperature also decreased. In these stations a high relative abundance of the copepods Paracalanus quasimodo and Temora turbinata occurred. 
FIGURE 3: Taxonomic richness ( $\mathrm{n}^{\mathrm{o}}$ of taxa) (A) and zooplankton community density (B).

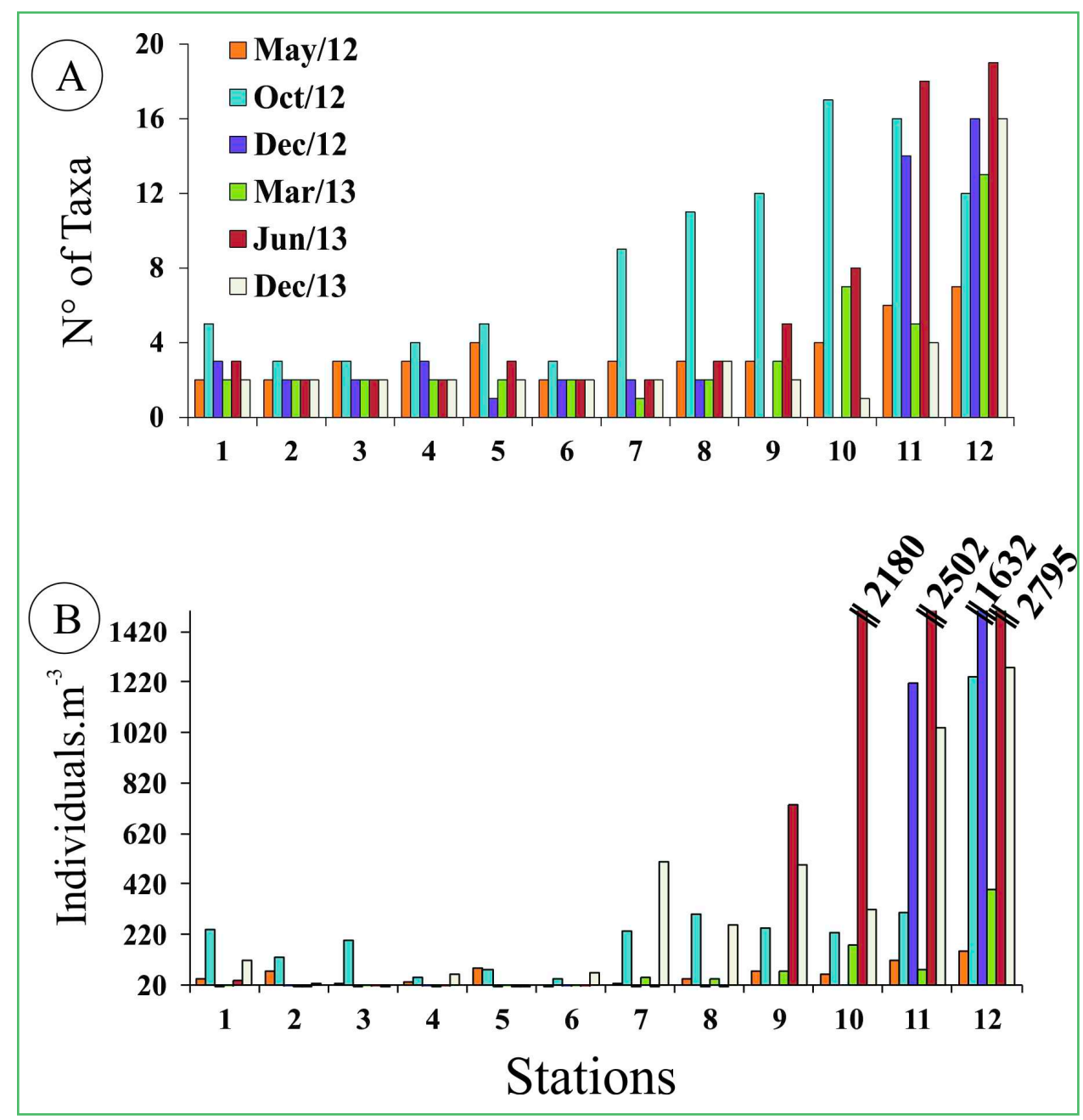

TABLE 2: Frequency of occurrence (\%) and relative abundance (\%) of the most representative species.

\begin{tabular}{cccc}
\hline Frequency of occurrence & \% & Relative abundance & $\%$ \\
\hline Acartia tonsa & 99 & Acartia tonsa & 36 \\
Cirripedia larvae & 80 & Cirripedia larvae & 18 \\
Oithona hebes & 23 & Temora turbinata & 14 \\
Paracalanus quasimodo & 19 & Paracalanus quasimodo & 6 \\
Temora turbinata & 19 & Pseudoevadne tergestina & 5 \\
Decapoda larvae & 17 & Penilia avirostris & 5 \\
Oithona nana & 10 & Oncaea media & 4 \\
Parasagitta tenuis & 10 & & \\
\hline
\end{tabular}


Shannon diversity variability was low over the year (annual average of $0.7 \pm 0.5$ bits.ind $^{-1}$ ), the minimum 0.4 bits.inds $^{-1}$ was recorded at stations 2 and 8 and the maximum 1.7 bits. ind ${ }^{-1}$ at station 12 . The evenness also had low variability throughout the year, with a minimum of 0.5 at station 8 and 0.8 at station 5 with a maximum average of $0.7 \pm 0.2$ (Figure 4 ).

The MDS analysis showed that stations 1 to 8 and from 9 to 12 are more similar to each other (Figure 5). The SIMPER analysis showed a high contribution of Acartia tonsa (67\%) and Cirripedia larvae (26\%) in stations 1 to 11 . In station 12 was recorded the highest diversity, Temora turbinata (31\%), Paracalanus quasimodo (21\%), Pseudoevadne tergestina (6,54\%) and Decapoda larvae $(3,77 \%)$ had also a high contribution in the community composition and abundance. Interestingly, the decrease in the dominance of $A$. tons $a$ leaded to the diversification of station 12 from the others (Figure 6) and the cluster of stations 10, 11 and 12 in the MDS analysis (Figure 5).

ANOSIM analysis presented significant results for temporal variation. Sample statistic (Global R): 0.198. Significance level of sample statistic: $0.01 \%$. Number of permutations: 9999 . ANOSIM analysis also presented significant result for spatial variation. Sample statistic (Global R): 0.211. Significance level of sample statistic: $0.01 \%$. Number of permutations: 9999.

\section{Discussion}

Our major findings highlight that after station 7 the number of taxa and the density in the lagoon increase. The average abundance is low, but in station 10, 11 and 12 it is relatively high. The low taxonomic number and the low density of the zooplankton community in the lagoon were also mentioned by Rodrigues (1998) in the 1990's. As in the Rodrigues (1998) results, zooplankton has a higher density in seaside stations (near station 7 and 8). In another study of hypersaline estuary zooplankton, it is demonstrated that in salinity between 41-50 the zooplankton community exhibits fewer taxa and a low average abundance (BUSKEY et al., 1998; COUTINHO et al., 1999).

The higher density and richness near the sea (stations 12,11, 10 and 9) can be caused by the variation of the tide that influences the estuarine channels, revealing a zooplankton community with greater diversity at high tide (MELO et al., 2008). Most of the organisms have a maximum and minimum tolerance to variations of salinity $(15 \%$ o to $38 \%$ o) and temperature $\left(10^{\circ} \mathrm{C}\right.$ to $\left.30^{\circ} \mathrm{C}\right)$, while the values of these parameters in the lagoon are above the tolerance limit of most of the species (DRILLET et al., 2011).

In station 12, the species with the highest density were Paracalanus quasimodo (species found in neritic and coastal waters, thermophilic) and Temora turbinata,

FIGURE 4: Species diversity (H') and Evenness (J) of the zooplankton community in the Araruama Lagoon.

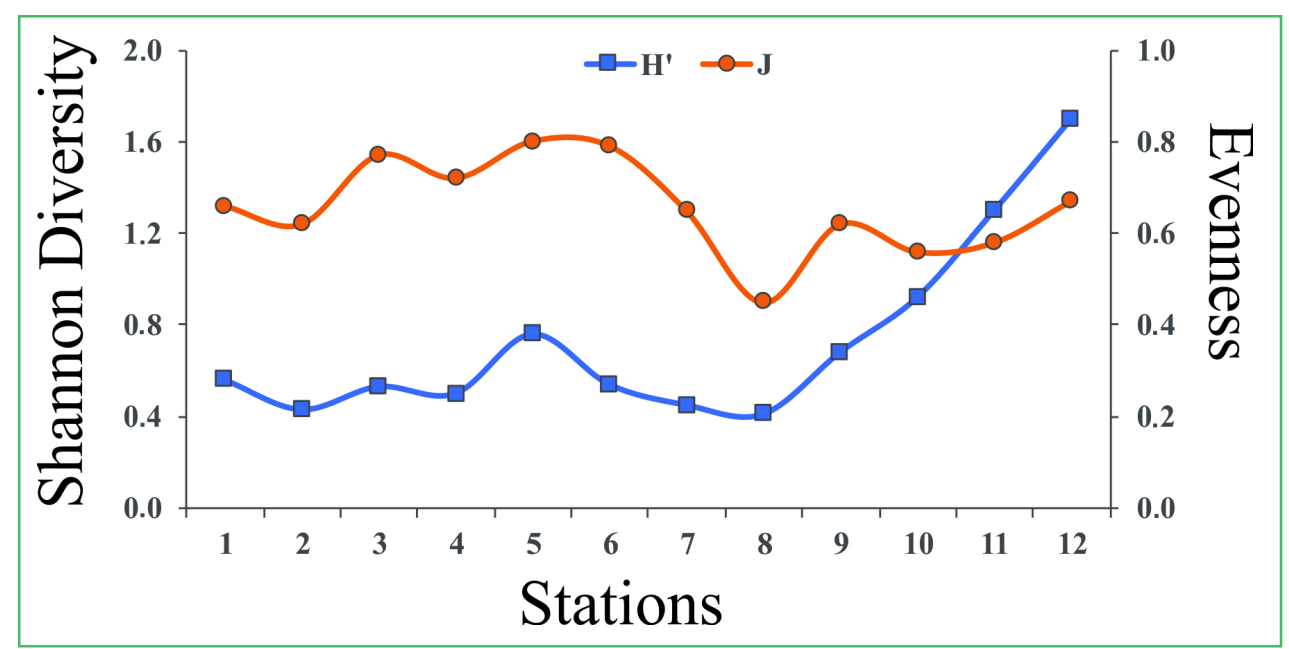


FIGURE 5: MDS chart. Distribution of 12 stations after 2 years of collection.

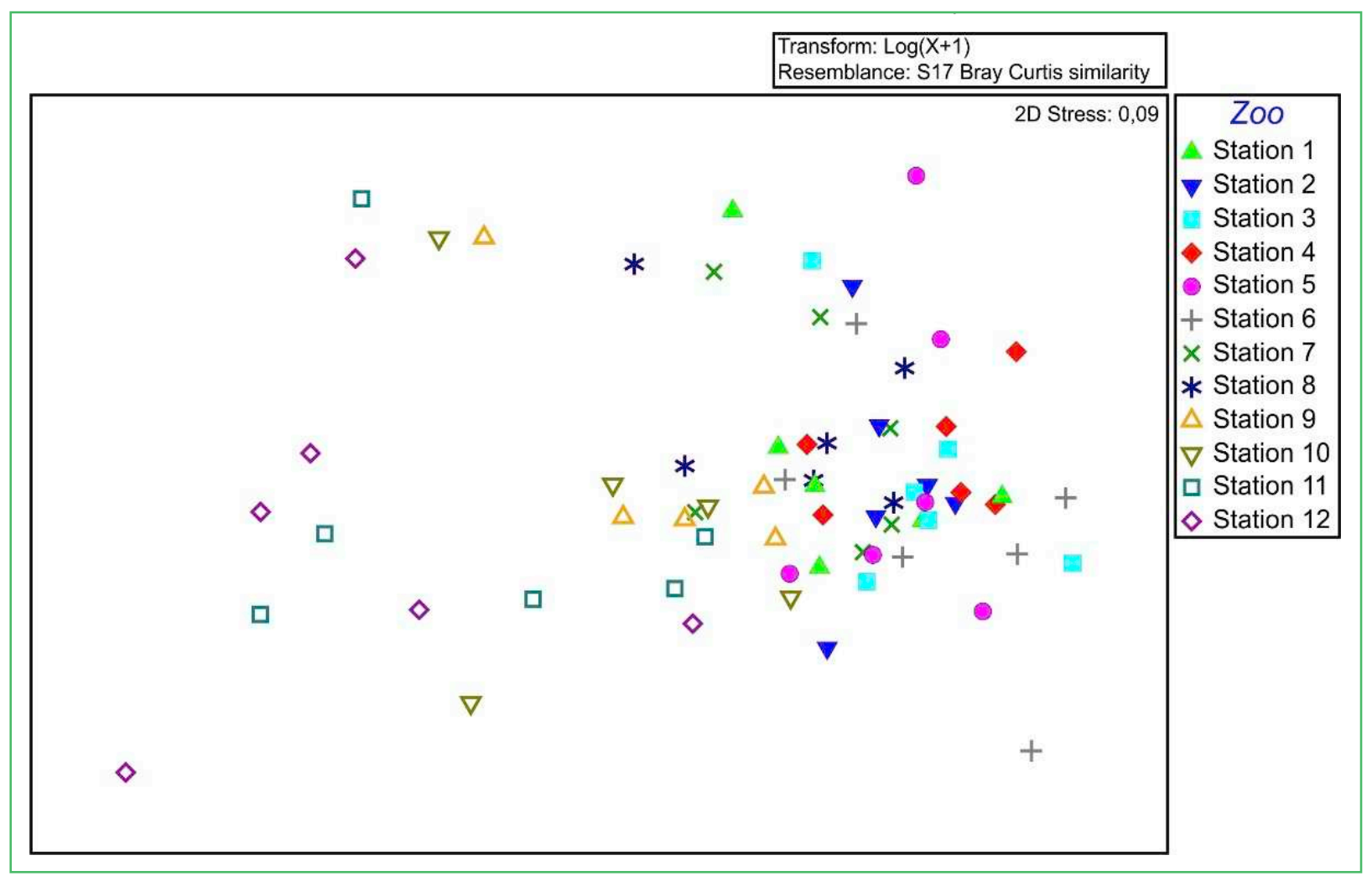

FIGURE 6: Similarity (SIMPER) of each station with the contribution of each most representative individuals (with a contribution above $3 \%$ ).

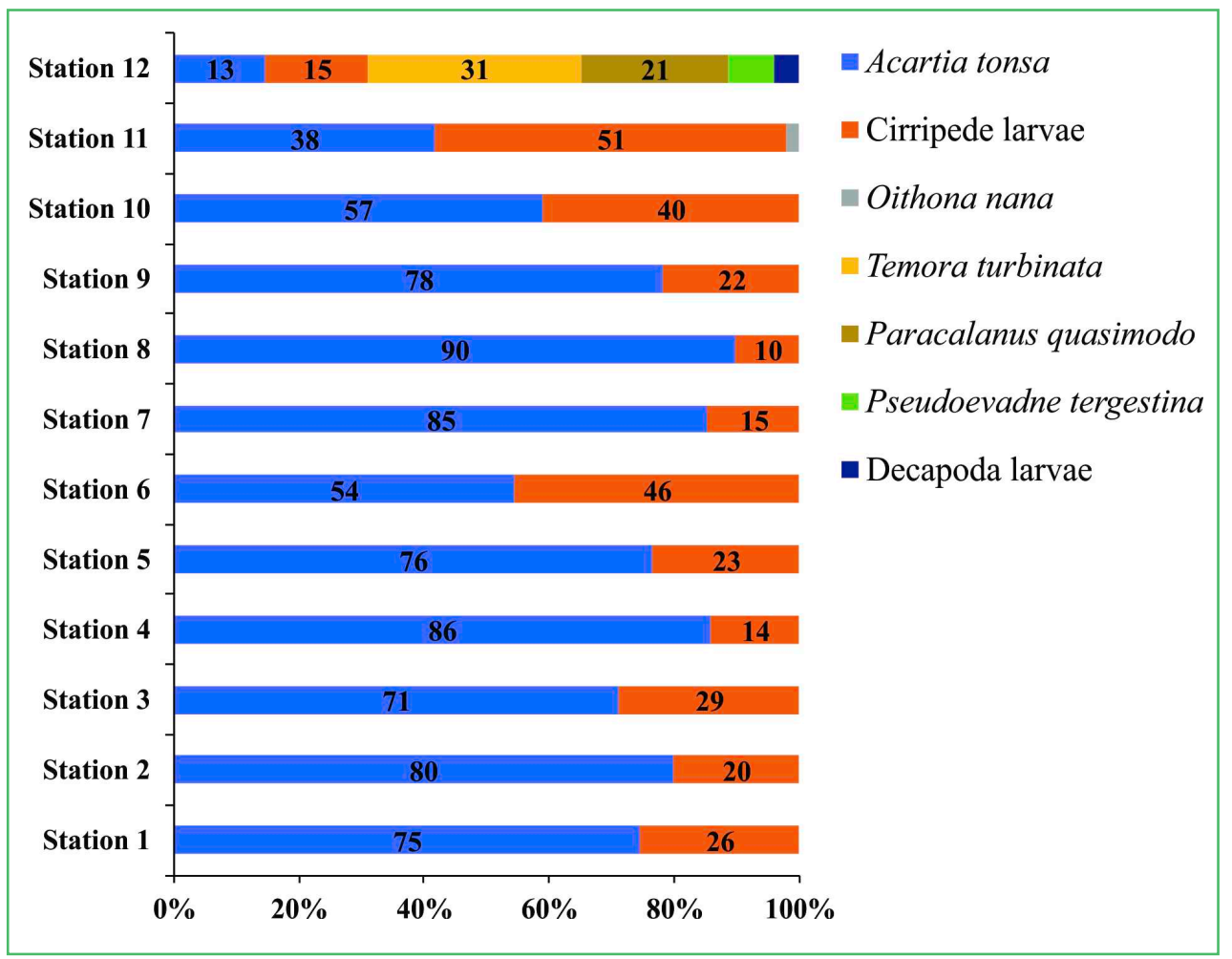


(found in coastal and oceanic waters) (DIAS; ARAUJO, 2006). Temora turbinata is one of the dominant species in estuarine environments with a wide distribution along the Brazilian coast (SANTOS et al., 2009). This species is invasive to the Brazilian coast, (VILLAC et al., 2009), which it was first mentioned in the northeast region in the 80's (ARAÚJO; MANTU, 1993).

The present study showed that Acartia tonsa was the most representative copepoda. In the past, it was also reported the dominance of the copepods Acartia lilljeborgi (MONTEIRO-RIBAS, 1978) and Oithona hebes (RODRIGUES, 1998) in the Araruama Lagoon. In the present study, O. hebes was poorly abundant and A. lilljeborgi was found only in station 12 , close to the seawater entrance. This variation in species may be related to the changes in salinity over the years, which decreased the average from $64 \%$ to $41 \%$ over the last 40 years (ROSA et al., 2016a).

The high relative abundance and frequency of occurrence of the genus Acartia is a strong indicator of eutrophication (COELHO-BOTELHO et al., 1999). The high number of this copepoda species also means that $A$. tonsa is adapted to the conditions of the lagoon just as O. hebes (RODRIGUES, 1998). Besides meroplankton also changed in terms of density and composition. In the present study the Cirripedia larvae was abundant, while in the 1990's Bivalve larvae dominated (RODRIGUES, 1998). The fact of the copepoda A. tonsa and the Cirripedia larvae being more abundant in the lagoon may be related to the current salinity variability in the lagoon, that is more suitable for these species (WOOLDRIDGE; DEYZEL, 2009). The higher abundance of Cirripedia larvae in May 2012 may be related to phytoplankton blooms, due to higher food availability their larvae (ROSA, 2016).

Currently, the density of Euterpina acutifrons is very low both in coastal regions and in the Araruama Lagoon. The copepoda $E$. acutifrons was very representative in the Araruama Lagoon in the 1990's in locations where the salinity was lowest, such as the coastal regions in Cabo Frio (RODRIGUES, 1998). According to Rosa et al. (2016b), the introduction of the invasive species Temora turbunata affected the composition of the copepoda assembly.
The spatial and temporal variability of the present study demonstrated greater richness and abundance towards the seaside, results similar to the previous studies, which also seems to be related to the high tide (ROBERTSON et al., 1988). The holoplankton presented dominance during the study period and the meroplankton larvae (mainly Cirripedia) are very representative on some occasions, this variation may be related to the reproductive period of barnacles. Over the years the dominant copepoda species have been changing as well as the meroplankton larvae. These changes may be related to salinity that has been decreasing over the years.

\section{References}

ANGER, K. The biology of decapod crustacean larvae. Journal of Experimental Marine Biology and Ecology, Amsterdam, v. 14, p. 89-90, 2002.

ARAÚJO, H. M. P.; MONTU, M. Novo registro de Temora turbinata (Dana, 1849) (Copepoda, Crustacea) para águas Atlanticas. Nauplius, Botucatu, v. 1, p. 89-90, 1993.

BELGRANO, A.; LEGENDRE, P.; DEWARUMEZ, J. M.; FRONTIER, S. Spatial structure and ecological variation of meroplankton on the French-Belgian coast of the North Sea. Marine Ecology Progress Series, Luhe, v. 128, n. 1-3, p. 43-50, 1995.

BOLTOVSKOY, D. C. Atlas del zooplancton del Atlântico Sudoccidental metodos de trabajo com el zooplancton marine. Mar del Plata: INIDEP, 1981. 936 p.

BOLTOVSKOY, D. South Atlantic zooplankton. Leiden: Backhuys Publishers, 1999. 72 p.

BONECKER, A. C. T.; BONECKER, S. L. C.; BASSANI, C. Plâncton marinho. In: PEREIRA, R. C.; SOARES-GOMES, A (Ecd.). Biologia marinha. Rio de Janeiro: Interciência, 2009. p. 213-239.

BUSKEY, E. J.; WYSOR, B.; HYATT, C. The role of hypersalinity in the persistence of the Texas "brown tide" in the Laguna Madre. Journal of Plankton Research, Oxford, v. 20, n. 8, p. 1553-1565, 1998.

CALBET, A.; LANDRY, M. R.; SCHEINBERG, R. D. Copepod grazing in a subtropical bay: Species-specific responses to a midsummer increase in nanoplankton standing stock. Marine Ecology Progress Series, Luhe, v. 193, p. 75-84, 2000.

CARVAlHO, A. P. A. M.; COSTA, R. S.; ROSA, J. C. L. Eutrophication and introduction of exotic species in hipersaline estuary. In: SEMINÁRIO REGIONAL SOBRE GESTÃO DE RECURSOS HIDRICOS, IV, 2014, Campos dos Goytacazes. Anais... Campos dos Goytacazes: Instituto Federal Fluminense, 2014. p. 1-13.

CHEN, H.; LIU, G. Zooplankton community structure in the Yellow Sea and East China Sea in autumn. Brazilian Journal of Oceanography, São Paulo, v. 63, n. 4, p. 455-68, 2015. 
CLARKE, K. R.; AINSWORTH, M. A method of linking multivariate community structure to environmental variables. Marine Ecology Progress Series, Luhe, v. 92, p. 205-219, 1993.

CLARKE, K. R.; GREEN, R. H. Statistical design and analysis for a 'biological effects' study. Marine Ecology Progress Series, Luhe, v. 46, p. 213-226, 1988.

CLARKE, K. R.; P. J. SOMERFIELD, P. J.; CHAPMAN, M. G. On resemblance measures for ecological studies, including taxonomic dissimilarities and a zero-adjusted Bray-Curtis coefficient for denounced assemblages. Journal of Experimental Marine Biology and Ecology, Amsterdam, v. 330, p. 55-80, 2006.

COELHO-BOTElHO, M. J.; MAURO, J. B. N.; DIAS, C. de O.; KURTZ, F. W.; TRUZZI, A. C.; NOGUEIRA, C. R.; REIS, J. L.; MATHIAS, A. M. F. Aspectos do zooplâncton na baía de Sepetiba (RJ, Brasil). In: SILVA, S. H. G.; LAVRADO, H. P. (Ed.). Ecologia dos ambientes costeiros do estado do Rio de Janeiro. Ser. Oecologia Brasiliensis. Rio de Janeiro: PPGE-UFRJ, 1999. p. 1-33.

COSTA, D. F. S.; ROCHA, R. M.; BARBOSA, J. E. L.; SOARES, A. M. V. M.; LILlEBO, A. I. Análise dos serviços ambientais prestados pelas salinas solares. Boletim Gaúcho de Geografia, Porto Alegre, v. 41, p. 206-220, 2014.

COUTINHO, R.; RIBEIRO, P.; KJERFVE, B.; KNOPPERS, B.; MUEHE, D.; VALENTIN, J. L. Araruama, uma lagoa ameaçada. Ciência Hoje, Rio de Janeiro, v. 25, p. 24-31, 1999.

DIAS, C. O.; ARAUJO, A. V. Copepoda. In: BONECKER, S. L. C. (Ed.). Atlas da região central da zona econômica exclusiva brasileira. Rio de Janeiro: Museu Nacional, 2006. p. 23-101.

DRIRA, Z.; KMIHA-MEGDICHE, S.; SAHNOUN, H.; TEDETTI, M.; PAGANO, M.; AYADI, H. Copepod assemblages as a bioindicator of environmental quality in three coastal areas under contrasted anthropogenic inputs (Gulf of Gabes, Tunisia). Journal of the Marine Biological Association of the United Kingdom, Cambridge, v. 98, n. 8, p. 1889-1905, 2017.

DRILLET G.; FROUËL S.; SICHLAU M. H.; JEPSEN, P. M.; HØJGAARD, J. K. JOARDEER, A. K. HANSEN, B. W. Status and recommendations on marine copepod cultivation for use as live feed. Aquaculture, Amsterdam, v. 3, n. 315, p. 155-166, 2011.

FERNANDES, L. D. A.; NETTO, E. B. F.; COUTINHO, R. Interannual cascade effect on marine food web: a benthic pathway lagging nutrient supply to pelagic fish stock. Plos One, Cambridge, v. 12 , n. 9 , p. $1-18,2017$.

FIELD, J. G.; CLARKE, K. R.; WARWICK, R. M. A practical strategy for analysing multispecies distribution patterns. Marine Ecology Progress Series, Luhe, v. 8, p. 37-52, 1982.

HIRST, A. G.; BUNKER, A. J. Growth of marine planktonic copepods: global rates and patterns in relation to chlorophyll a temperature, and body weight. Limnology and Oceanography, Newfoundland, v. 48, n. 5, p. 1988-2010, 2003.

McCUNE, B.; GRACE, J. B. Analysis of ecological communities. Gleneden Beach: MjM Software, 2002. 304 p.

MELO, P. A. M. C.; NEUMANN-LEITÃO, S.; GUSMÃO, L. M. O; PORTO NETO, F. F. Variação nictemeral do macrozooplâncton na Barra Orange - Canal de Santa Cruz, estado de Pernambuco (Brasil). Revista Brasileira de Engenharia de Pesca, São Luís, v. 3 , n. 2 , p. $30-49,2008$.
MONTEIRO-RIBAS, W. M. O zooplâncton das águas hipersalinas da Lagoa de Araruama (Brasil). Observações preliminares. Cabo Frio: Instituto de Pesquisas da Marinha, 1978. 13 p. (Relatório interno)

PEREIRA, L. F. M. A gestão participativa no caso do saneamento da região dos Lagos, Rio de Janeiro. Revista Discente Expressões Geográficas, Florianópolis, n. 3, p. 10-41, 2007.

ROBERTSON, A. I.; DIXON, P.; DANIEL, P. A. Zooplankton dynamics in mangrove and other nearshore habitats in tropical Australia. Marine Ecology Progress Series, Luhe, v. 43, p. 139150, 1988.

ROBINSON, K. L.; RUZICKA, J. J.; DECKER, M. B.; BRODEUR, R. D.; HERNANDEZ, F. J.; QUIÑONES, J.; ACHA, E. M.; UYE, S. I.; MIANZAN, H.; GRAHAM, W M. Jellyfish, forage fish, and the world's major fisheries. Oceanography, Washington, v. 27, n. 4, p. 104-15, 2014.

RODRIGUES, C. L. O zooplâncton da laguna hipersalina de Araruama (RJ) com ênfase na biologia de Oithona oswaldocruzi Oliveira, 1945 (Cyclopoida, Copepoda). 1998. 130 f. Dissertação (Mestrado em Zoologia) - Universidade Federal do Rio de Janeiro, Rio de Janeiro. 1998.

ROSA, J. C. L. Variação temporal da assembleia meroplanctônica com ênfase em larvas de cirrípedes e mitilídeos em região de ressurgência. 2016. Dissertação (Mestrado em Dinâmica dos Oceanos e da Terra) - Universidade Federal Fluminense, Niterói. 2016.

ROSA, J. C. L.; ALBERTO, M. D.; RIBAS, W. M. R.; BAETA NEVES, M. H. C.; FERNANDES, L. D. A. Spatial variability in the icthyoplankton structure of a subtropical hypersaline lagoon. Brazilian Journal of Oceanography, São Paulo, v. 64, n. 2, p. 149-156, 2016a.

ROSA, J. C. L.; MONTEIRO-RIBAS, W. M.; FERNANDES, L. D. A. Herbivorous copepods with emphasis on dynamic Paracalanus quasimodo in an upwelling region. Brazilian Journal of Oceanography, São Paulo, v. 64, n. 1, p. 67-74, 2016 b.

SANTOS, T. G.; GUSMÃO, L. M. O.; NEUMANN-LEITÃO, S.; CUNHA, A. G. Zooplâncton como indicador biológico da qualidade ambiental nos estuários dos rios Carrapicho e Botafogo, Itamaracá - PE. Revista Brasileira de Engenharia de Pesca, São Luís, v. 4, p. 45-56, 2009.

SCHUINDT, R. M. A.; DACO, R. S.; OLIVEIRA, M. M. Impactos na Lagoa de Araruama e percepção ambiental da comunidade da Praia do Siqueira, Cabo Frio (RJ). Revista Brasileira de Educação Ambiental, Diadema, v. 13, n. 1, p. 299-321, 2018.

SHAPIRO, A. S. S.; WILK, M. B. An Analysis of Variance Test for normality (complete samples). Biometrika, Oxford, v. 52, p. 591-611, 1965.

VILLAC, M. C.; LOPES, R. M.; RIVERA, I. N. G.; BASSANELLO, R. T.; CUNHA, D. R.; FILHO, J. E. M.; SANTOS, D. B. Plâncton. In: LOPES, R. (Ed.). Espécies exóticas invasoras marinhas no Brasil. Brasília: Ministério do Meio Ambiente, 2009. p. 39-104.

WOOLDRIDGE, T. H.; DEYZEL, S. H. P. Temperature and salinity as abiotic drivers of zooplankton community dynamics in the Great Berg Estuary. Transactions of the Royal Society of South Africa, Cape Town, v. 64, p. 219-237, 2009. 